\title{
PENGARUH MINAT BELAJAR KETERSEDIAAN SARANA PENDIDIKAN DAN KOMPETENSI DOSEN TERHADAP PEMAHAMAN PSAK KONVERGENSI
}

\section{INFLUENCE OF ENTHUSIASM LEARN THE AVAILIBILITY OF MEDIUM EDUCATION AND INTEREST LECTURER TO UNDERSTANDING OF CONVERGENCE PSAK}

\author{
D.S. Gustiani, J. Marsudi \\ Jurusan Akuntansi Fakultas Ekonomi Universitas Djuanda \\ E-mail : delitadcasd@gmail.com
}

\begin{abstract}
Understanding of Convergence PSAK become matter off necessary for accounting majors student to make financial statement matching with standard and can be accepted public so that yield accounting grads owning science stock concerning Convergence PSAK. Population in this research is student of S-1 Program Study Accounting College which is have active status to in Town of Bogor that is 571 student. Intake of sample done by using method of proportionate sampling random stratified, of the method can be determined by the amount of sample counted 235 by using primary data and instrument of questionnaires. Technique analyse data the used is technique analyse multiple regression. Result of research of indicates that student of S-1 Program Study Accounting in Town of Bogor woman majority which is have age to between 21-25 year with previous education background of majors of IPS. As for result of student comments of Enthusiasm Learn, Availibility of Medium Education, and Interest Lecturer have an effect on either through and also simultaneous of partial to Understanding of Convergence PSAK with contribution equal to 51 gratuity and Interest Lecturer become dominant variable.
\end{abstract}

Keyword : Enthusiasm Learn, Medium Education, Interest Lecturer, Understanding of Convergence PSAK.

\begin{abstract}
ABSTRAK
Pemahaman PSAK Konvergensi menjadi hal penting bagi mahasiswa jurusan akuntansi untuk membuat laporan keuangan yang sesuai dengan standar dan dapat diterima umum sehingga menghasilkan lulusanlulusan akuntansi yang memiliki bekal ilmu pengetahuan mengenai PSAK Konvergensi. Populasi dalam penelitian ini adalah mahasiswa S-1 Program Studi Akuntansi Perguruan Tinggi yang berstatus aktif di Kota Bogor yaitu 571 mahasiswa. Pengambilan sampel dilakukan dengan menggunakan metode proportionate stratified random sampling, dari metode tersebut dapat ditentukan jumlah sampel sebanyak 235 dengan menggunakan data primer dan instrumen kuesioner. Teknik analisis data yang digunakan adalah teknik analisis regresi berganda. Hasil penelitian menunjukan bahwa mahasiswa S-1 Program Studi Akuntansi di Kota Bogor mayoritas perempuan yang berusia antara 21-25 tahun dengan latar belakang pendidikan sebelumnya dari jurusan IPS. Adapun hasil tanggapan mahasiswa atas Minat Belajar, Ketersediaan Sarana Pendidikan, dan Kompetensi Dosen berpengaruh baik secara simultan maupun parsial terhadap Pemahaman PSAK Konvergensi dengan kontribusi sebesar 51 persen dan Kompetensi Dosen menjadi variabel yang dominan.
\end{abstract}

Kata kunci : Minat Belajar, Sarana Pendidikan, Kompetensi Dosen, Pemahaman PSAK Konvergensi. 


\section{PENDAHULUAN}

Sistem informasi keuangan suatu perusahaan digunakan sebagai penyedia informasi pada suatu perusahaan baik diluar perusahaan mengenai masalah keuangan yang sesuai dengan ketentuan dalam standar, seiring adanya kompetensi global yang berakibat pada transaksi bisnis menjadi semakin berkembang. Pada era globalisasi SAK (Standar Akuntansi Keuangan) mengalami perkembangan yang pesat dimana setiap perusahaan mulai mencatat LK (Laporan Keuangan) dengan menggunakan standar (pelaporan keuangan internasional) (International Financial Reporting standard). Perusahaan bonavid yang sudah tercatat di bursa efek asing harus membuat laporan keuangan sesuai dengan standar keuangan di negara tersebut dengan mengubah standar pelaporan keuangan yang pada mulanya menggunakan GAAP (Generally Accepted Accounting Principle) menjadi IFRS (International Financial Reporting standard). Lulusan perguruan tinggi Indonesia sedang mengalami situasi sulit dalam memperoleh pekerjaan dan terlihat dari jumlah pengangguran terdidik Indonesia yang meningkat setiap tahunnya. Yang dipublikasi dari data BPS (Badan Pusat Statistik) pada Agustus 2014, di Indonesia ada 9,5 persen (688.660 orang) dari total penganggur yang merupakan alumni perguruan tinggi

(http://www.edukasi.kompas.com). Kesulitan tamatan sekolah tinggi/perguruan tinggi yang akan terserap pada persaingan pekerjaan selalu meningkat, dikarenakan mereka juga akan memiliki persaingan dengan pekerja luar negeri dari Negara ASEAN lainnya sebagai dampak berlakunya Masyarakat Ekonomi Asean

Faktor yang menyebabkan sulitnya tamatan PT (Perguruan Tinggi) mendapatkan pekerjaan yaitu karena lulusan tersebut tidak memenuhi standar yang telah diatur oleh perusahaan, sedangkan pada dasarnya perusahaan masih membutuhkan pekerja yang handal di bidangnya, terutama pada pekerja pada bidang akuntansi. Oleh sebab itu Indonesia dituntut untuk dapat meningkatkan jumlah akuntannya, dan akuntan Indonesia didorong untuk memiliki sertifikasi kompetensi yang berlaku internasional. Jumlah akuntan di Indonesia berada di posisi keempat setelah, Malaysia, Thailand dan Singapura, kemudian ancaman datang dari Negara tersebut, sebab jika dibandingkan jumlah akuntan di Indonesia terbilang masih sedikit dibandingkan dengan jumlah penduduuk Indonesia yaitu 248.818,1 penduduk dengan jumlah akuntan sebanyak 24.587, padahal berbanding dengan Negara Asean lain seperti Negara Thailand jumlah penduduk sebanyak $68.251,0$ penduduk dengan menghasilkan akuntan sebanyak 62.739. Hal ini menjadikan IAI selaku pihak yang professional dalam ilmu akuntansi serta harus terus berupaya melakukan sertifikasi kepada akuntan serta dapat menjadi akuntan yang professional.

Tantangan Akuntan dalam menyambut Masyarakat Ekonomi Asean seharusnya dapat disadari oleh lembaga pendidikan terutama PT (Perguruan Tinggi) dengan penambahan materi PSAK Konvergensi yang dapat menambah pemahaman mahasiswa dalam pengajaran matakuliah akuntansi sehingga menghasilkan lulusan-lulusan akuntansi yang telah memiliki bekal pengetahuan mengenai IFRS. Herbert (2013:122), mengemukakan bahwa salah satu tantangan yang dihadapi dalam proses implementasi adalah kekurangan akuntan yang terampil dan auditor yang berkompeten dalam implementasi IFRS. Pemahaman dalam pembelajaran diharapkan dapat membuat seseorang mampu memahami arti atau konsep, situasi, serta fakta yang diketahuinya. PT (Perguruan Tinggi) tentunya memberikan pemahaman yang memiliki perbedaan dengan perguruan tinggi lainnya, baik itu dari sisi kompetensi pengajar, metode pembelajaran yang disampaikan dosen kepada mahasiswanya, maupun dari sisi ketersediaan informasi didalam PT (Perguruaan Tinggi) tersebut. Perbedaan ini bisa mengakibatkan tingkat kefahaman mahasiswa akuntansi terhadap pemahaman PSAK konvergensi.

Kota Bogor menjadi kota yang diminati mahasiswa untuk melanjutkan pendidikan, mulai dari sekolah tinggi, universitas, hingga sebuah institut hadir di Kota Bogor. Terbukti dengan adanya peningkatan jumlah mahasiswa pada Kota Bogor dilatarbelakangi pendidikan program studi yang dipublikasi Bogor dalam angka (2015), dari tahun 2013 sebanyak 24.547 mahasiswa dan tahun 2014 sebanyak 49.967 mahasiswa, sehingga mahasiswa dapat menentukan PT (Perguruan Tinggi) yang sesuai pilihannya, terutama pada program studi akuntansi yang berpotensi besar untuk dapat memahami PSAK Konvergensi IFRS. Adapun jumlah mahasiswa aktif S-1 program studi akuntansi di Kota Bogor setelah melakukan observasi yaitu sebanyak 3.145 mahasiswa di tahun 2016 yang tersebar dibeberapa perguruan tinggi, diantaranya : Universitas Pakuan, STIE (Sekolah Tinggi Ilmu Ekonomi) Kesatuan, Universitas Nusa Bangsa, STIE (Sekolah Tinggi Ilmu Ekonomi) Triguna. Hal ini berkaitan dengan perusahaan yang terdapat di Kota Bogor terbilang cukup banyak dilihat dari jumlah perusahaan di Kota Bogor dari data BPS (2014) sebanyak 746 diantaranya dari perusahaan besar, perusahaan menengah, perusahaan kecil, dan perusahaan mikro. Dengan demikian total tersebut bisa diketahui kebutuhan 
akan akuntan pada perusahaan terutama perusahaan besar memerlukan akuntan untuk bisa membuat LK (Laporan Keuangan) serta bisa diterima oleh umum. Tetapi menurut observasi yang sudah dilaksanakan kepada mahasiswa akuntansi, bahwa mahasiswa akuntansi relatif kurang akan pemahaman PSAK konvergensi. Padahal perusahaan memerlukan para pekerja berkompeten dibidangnya, karena akuntan memiliki peranan penting perusahaan. Mahasiswa di Kota Bogor yang akan masuk di dunia kerja selepas menyelesaikan jenjang pendidikan, tentunya harus dapat bersaing dengan calon pekerja lain, baik itu di Kota Bogor ataupun di luar Kota Bogor. Berdasarkan uraian tersebut, penulis tertarik dapat melaksanakan penelitian berjudul "Pengaruh Minat Belajar, Ketersediaan Sarana Pendidikan, dan Kompetensi Dosen Terhadap Pemahaman PSAK Konvergensi".

Tujuan pada penelitian ini yaitu:

1. Untuk mengetahui karakteristik dan deskripsi mahasiswa program studi akuntansi S-1 di Kota Bogor.

2. Untuk mengetahui apakah minat belajar, ketersediaan sarana pendidikan, dan kompetensi dosen berpengaruh secara simultan terhadap pemahaman PSAK Konvergensi.

3. Untuk mengetahui apakah minat belajar, ketersediaan sarana pendidikan, dan kompetensi dosen berpengaruh secara parsial terhadap pemahaman PSAK Konvergensi.

4. Untuk mengetahui faktor yang paling dominan dalam mempengaruhi pemahaman PSAK Konvergensi.

Dengan dilakukannya penelitian ini dimaksudkan bisa memberkan manfaat yng baik bagi peneliti, bagi mahasiswa studi akuntansi, bagi lingkungan akademik, dan juga bagi lingkungan bisnis. Karena penelitian ini dapat memperluas wawasan penulis dan memperbanyak ilmu pengetahuan, untuk memperbanyak informasi bagi mahasiswa dalam bidang akuntansi keuangan khususnya dalam pemahaman PSAK konvergensi IFRS, dan sebagai proses pengembangan ilmu pengetahuan bagi lingkungan akademik khususnya dalam pemahaman PSAK konvergensi IFRS, juga penelitian ini dimaksudkan dapat menjadi informasi bagi lembaga/organisasi terkait guna meningkatkan mutu lulusan akuntan sebagai pekerja intelektual yang seimbang dengan pasar kerja.

\section{TINJAUAN TEORI DAN PENGEMBANGAN HIPOTESIS}

\section{Minat Belajar}

Minat belajar ialah suatu aspek yang dapat memberikan semangat (motivasi) pada orang demi mewujudkan tujuannya dan suatu kondisi seseorang memiliki perhatian menganai sesuatu \& diiringi dengan kemauan yang tinggi. Slameto (2010:57), minat yaitu cenderung yang tetap dalam memperhatikan dan mengingat suatu kejadian dan kegiatan. Kegiatan itu diminati, diikuti secara berulangkali dengan diikuti perasaan bahagia sehingga diperoleh kepuasan. Tu'u (2004:79), minat ialah cenderungan yang banyak pada sesuatu. Seseoarang yang telah mempunyai minat terhadap suatu pelajaran terpilih cenderung dapat memperhatikannya dengan baik. Sedangkan definisi belajar menurut Slameto (2010:2), belajar adalah sebuah cara usaha yang dillaksanakan seseorang agar dapat mencapai perubahan sikap yang baru secara keseluruhan, menjadi hasil pengetahuan sendiri dalam komunikasinya dengan lingkungan.

\section{Ketersediaan Sarana Pendidikan}

Ketersediaan sarana pendidikan adalah hal yang mendorong cara belajar membimbing, karena dengan ketersediaan sarana yang lengkap seperti buku-buku, akses internet dan media belajar dapat menjadi informasi yang berguna serta dapat memotivasi individu dalam hal belajar.

Menurut KBBI (Kamus Besar Bahasa Indonesia), definisi sarana ialah yang dipakai sebagai peralatan agar menggapai makna dan tujuan, sedangkan Mulyasa (2004:49), menyatakan bahwa sarana pndidikan adalah perlengkapan dan peralatan secara langsung yang dipakai serta membantu proses pendidikan, hususnya kegiatan belajar, mengajar seperti bangunan (gedung), bagian kelas, meja \& kursi, serta peralatan media pelajaran. Suwardjono dalam hanifah dan syukriy (2001) yang dikutip oleh Nugraheni (2012:16), menyatakan bahwa belajar diperguruan tinggi merupakan suatu pilihan strategi untuk memenuhi suatu tujuan seseorang.

\section{Kompetensi Dosen}

Kompetensi merupakan gabungan pengetahuan, prilaku, serta keahlian yang dapat dimiliki dosen untuk bisa memenuhi suatu tujuan pembelajaran. Wibowo (2007:86), kompetensi dinilai seperti keahlian untuk melaksanakan pekerjaan maupun kewajiban yang didampingi dengan keahlian (keterampilan) serta ilmu yang seharusnya dimiliki pekerja . Sedangkan Suyuti dalam Utami (2012:15), menyatakan bahwa kompetensi adalah kemampuan individual dan mampu menguasai atau melaksanakan suatu pekerjaan serta mampu menganalisis pekerjaan atau peraturan-peraturan kerja.

\section{Pemahaman PSAK Konvergensi}


Pemahaman merupakan kemampuan seseorang dalam mengartikan sesuatu melewati kegiatan belajar. Utami (2012:20), dalam KBBI (Kamus Besar Bahasa Indonesia), "paham" memiliki arti pandai atau mengerti benar sedangkan "pemahaman" adalah usaha, tata cara, memahami dan memahamkan. Sulastri dalam Christiani (2015:10), mengemukakan bahwa pemahaman merupakan kemampuan seseorang untuk mengerti dan memahami sesuatu setelah sesuatu tersebut diketahui dan diingatkan.

Pemahaman PSAK Konvergensi ialah sesuatu keahlian suatu orang agar mengenal, mengerti dan memahami standard dan keteapan yang berlaku IFRS. Tingkat pemahaman IFRS di ukur dari seberapa jauh orang tersebut mengetahui dan mengerti IFRS. Pemahaman IFRS ini terbagi menjadi 2 tingkatan yaitu pemahaman dasar dan pemahaman IFRS secara keseluruhan.

Konvergensi merupakan pedoman dari sekelompok entitas internl dan eksternal proses perkembangan. Mahendra (2013:28), arti konvergensi yang diambil dari kata convergence adalah keadaan menuju 1 titik pertemuan memusat. Sehingga prises konvergensi dari PSAK ke IFRS dapat diartikan sebagai PSAK yang akan dibawa pada suatu titik pertemuan dengan IFRS.

\section{Pengembangan Hipotesis Pengaruh Minat Belajar terhadap Pemahaman PSAK Konvergensi}

Minat adalah kecemderungan yang tetap agar melihat serta membayangkan sebagian kesibukan. kesibukan itu diminati, dilihat terusmenerus dan didampingi perasaan bahagia sehingga diperoleh kepuasan (Slameto, 2010:57). Artinya dengan memiliki minat belajar yang banyak kepada matakuliah yang memiliki hubungan terhadap PSAK Konvergensi dengan didampingi perasaan bahagia dan memperhatikan secara terus menerus, kemudian memiliki pengaruh kepada pemahaman PSAK Konvergensi. Nugraheni (2012:26), menunjukan bahwa ada pengaruh minat belajar terhadap pemahaman IFRS.

H1 : Diduga Minat belajar berpengaruh positif dan signifikan terhadap pemahaman PSAK Konvergensi

\section{Pengaruh Ketersediaan Sarana Pendidikan terhadap Pemahaman PSAK Konvergensi}

Sarana dari pendidikan adalah perlengkapan dan peralatan yang secara langsung yang dipakai serta membantu proses pendidikan, hususnya kegiatan belajar, mengajar seperti bangunan (gedung), bagian kelas, meja \& kursi, serta peralatan media pelajaran. (Mulyasa, 2004: 49). Artinya dengan tersedianya sarana dari pendidikan menunjang prosess belajar karena dengan tersedianya sarana pendidikn yang lengkap dapat menunjang proses belajar dan dapat menjadi laporan yang berguna pada saat proses belajar, segingga tersedianya sarana pendidikan dianggap pentig dan memiliki pengaruh terhadap pemahaman PSAK Konvergensi. Widaningrum (2010:19), menunjukan bahwa ada pengaruh keterseediaan sarana terhadap tingkat pemahaman mahasiswa akuntansi tentang IFRS. Utami (2012:29), menunjukan bahwa ada pengaruh persepsi mahasiswa mengenai kompetensi dosen terhadap pemahaman IFRS.

$\mathrm{H} 2$ : Diduga Minat belajar berpengaruh positif dan signifikan terhadap pemahaman PSAK Konvergensi.

\section{Pengaruh Kompetensi Dosen terhadap Pemahaman PSAK Konvergensi}

kompetensi dinilai seperti keahlian untuk melaksanakan pekerjaan maupun kewajiban yang didampingi dengan keahlian (keterampilan) serta ilmu yang seharusnya dimiliki pekerja (Wibowo, 2007:86). Artinya dosen yang kompeten memiliki kontribusi yang bermanfaat pada proses mengajar serta sebagai sumber pengetahuan ilmu serta mengarahkan mahasiswa ke lingkungan yang baik, memotivasi mahasiswa supaya bertambah aktif dan semangat belajar dengan pengetahuan \& keterampilan yang dimilikinya. Utami (2012:29), menunjukan bahwa apabila mahasiswa mempunyai persepsi bahwa dosen akan memotivasi mahasiswa untuk menyukai bahan ajar yang diterangkan dosen kemudian mahasiswa akan mempelajarinya, apabila dosen pengampu mereka berkompeten sehingga mahasiswa dapat mempunyai motivasi belajar tinggi karena nyaman yang dirasakan mahasiswa serta beranggapan dosen dapat dijadikan tempat mendalami ilmu ketika mereka belum paham terhadap suatu materi.

H4 : Diduga Kompetensi dosen berpengaruh positif dan signifikan terhadap pemahaman PSAK Konvergensi.

\section{METODE PENELITIAN}

Penelitian ini meneliti tentang Minat Belajar, Ketersediaan Sarana Pendidikan, dan Kompetensi Dosen terhadap Pemahaman PSAK Konvergensi. Penelitian ini adalah penelitian kuantitatif. Penelitian ini dikategorikan metode penelitian survei yang bersifat deskriptif, dengan teknik asosiatif kausal. Penggunaan teknik asosiatif kausal yaitu mengujii hipotesis hubungan variabel sebanyak dua atau lebih yang mengandung sebab 
akibat dan biasanya diawali dengan kata pengaruh atau faktor determinan.

Variabel Penelitian dan Operasionalisasi Variabel

Variabel bebas (variabel independen) pada penelitian ini ialah Minat Belajar $\left(\mathrm{X}_{1}\right)$, Ketersediaan Sarana Pendidikan $\left(\mathrm{X}_{2}\right)$, dan Kompetensi Dosen $\left(\mathrm{X}_{3}\right)$. Variabel Dependent dalam penelitian ini adalah (variabel terikat) Pemahaman PSAK Konvergensi. Indikator dari penelitian ini disajikan dalam tabel 1:

Tabel 1 : Operasional Variabel

\begin{tabular}{llcc}
\hline \multicolumn{1}{c}{ Variabel } & \multicolumn{1}{c}{ Indikator } & Skala Pengukuran & Pernyataan \\
\hline Minat Belajar $\left(\mathbf{X}_{\mathbf{1}}\right)$ & $\begin{array}{l}\text { a. Perasaan senang } \\
\text { b. Perhatian dalam belajar }\end{array}$ & & 1 \\
Aryanti(2010:26) & $\begin{array}{l}\text { c. Pengetahuan } \\
\text { d. Kesadaran }\end{array}$ & Skala Likert & 2 \\
& & & 4 \\
\hline
\end{tabular}

Ketersediaan Sarana

Pendidikan $\left(\mathbf{X}_{2}\right)$

Mulyasa (2004:49)
a. Gedung
b. Ruang Kelas
c. Meja Kursi
5
6

d. Alat-alat media pelajaran

Skala Likert

7
8

\section{Kompetensi Dosen $\left(\mathbf{X}_{3}\right)$}

UU No 14 Tahun 2005 dalam

Utami (2012:16)
a. Kompetensi Pedagogik
b. Kompetensi
Kepribadian
c. Kompetensi Sosial
Skala Likert

\section{9}
10

d. Kompetensi Profesional

11
12

\section{Pemahaman PSAK}

Konvergensi (Y)

Kieso (2011:77)
a. Tahap Pencatatan
b. Tahap Penggolongan
c. Tahap Peringkasan
d. Tahap Pelaporan
e. Tahap Penganalisisan

Skala Likert 


\section{Populasi, Sampel dan Teknik Pengambilan Sampel}

Populasi penelitian yang adalah mahasiswa S-1 akuntansi PT (Perguruan Tinggi) di Kota Bogor. Untuk pemilihan sampel menggunakan PSRS (Proportionate Stratified Random Sampling) serta memiliki kriteria mahasiswa yang masih berstatus aktif dan telah mengambil mata kuliah intermadite.

Berdasarkan hal tersebut pada penelitian ini diambil sampel data mahasiswa sesuai kriteria yaitu 235 responden.

\section{Pengujian Instrumen}

Berdasarkan data penelitian berupa kuesioner menurut Sugiyono (2013:136) data dapat diolah dengan skala pengukuran likert. Pengolahan data ordinal menjadi analisis regresi sebelumnya harus ditransformasikan ke bentuk data interval dengan menggunakan rumus :

$$
\frac{\text { Nilai Tertinggi-Nilai Terendah }}{\text { Banyaknya kelas }}=\frac{5-1}{5}=0,8
$$

Berdasarkan hasil perhitungan panjang kelas interval tersebut diperoleh kriteria penilaian pada Tabel 2 :

Tabel 2 : Skala Penelitian

\begin{tabular}{cc}
\hline Skala & Interpretasi \\
\hline $\mathbf{1 , 0 0}-\mathbf{1 , 8 0}$ & Sangat Tidak Baik \\
$\mathbf{1 , 8 1}-\mathbf{2 , 6 0}$ & Tidak Baik \\
$\mathbf{2 , 6 1}-\mathbf{3 , 4 0}$ & Cukup \\
$\mathbf{3 , 4 1}-\mathbf{4 , 2 0}$ & Baik \\
$\mathbf{4 , 2 1}-\mathbf{5 , 0 0}$ & Sangat Baik \\
\hline
\end{tabular}

Sumber : Sugiyono, 2014

\section{Pengujian Validitas}

Ghozali (2011:52), uji validitas digunakan untuk mengukur sah atau valid tidaknya kuesioner. Sugiyono (2013:183) Item instrumen dianggap valid jika koefisien $=$ atau $>0,3$, jika kurang dari 0,3 maka item instrumen tersebut dinyatakan tidak valid.

\begin{tabular}{|c|c|}
\hline $\begin{array}{l}\text { Corrected Item } \\
\text { Total Corelation }\end{array}$ & Keterangan \\
\hline$\geq \mathbf{0 , 3}$ & Valid \\
\hline$<0,3$ & Tidak Valid \\
\hline
\end{tabular}

Sumber : Sugiyono, 2013

\section{Pengujian Reliabilitas}

Sugiyono (2011:183), Uji Reliabilitas adalah pengukuran yang berkali kali menghasilkan data yang sama atau konsisten. Hasil pengujian reliabilitas menunjukan seberapa jauh suatu peralatan pengukuran bisa terpercaya/diandalkan melalui uji validitas dan dinyatakan layak (valid). Menguji reliabilitas maka digunakan rumus Alpha Cronbach. Kriteria suatu instrumen penelitian dikatakan reliabel dengan teknik ini, yaitu apabila reliabilitas instrumen rhitung $\geq 0,6$.

Tabel 4 : Kriteria Uji Reliabilitas

\begin{tabular}{cc}
\hline Alpha Cronbach & Keterangan \\
\hline $\mathbf{2 0 , 6}$ & Reliabel \\
$\mathbf{< 0 , 6}$ & Tidak Reliabel \\
\hline
\end{tabular}

Sumber : Sugiyono, 2007

\section{Uji Asumsi Klasik}

Pengujian hipotesis dilaksanakan sebelum terlebih dahulu dilakukan uji asumsi klasik yang mendasari penggunaan analisis regresi berganda. Persaman regresi dapat dikatakan baik untuk menggambarkan hubugan fungsional kelompok variabel tidak bebas jika persamaan tersebut memenuhi asumsi-asumsi regresi. Uji asumsi klasik atas data primer ini, maka dalam penelitian ini dilakukan uji normalitas, uji multikolonieritas, dan uji heteroskedastisitas.

\section{Metode Analisis Data}

Bentuk persamaan regresi yang dirumuskan berdasarkan hipotesis yang dikembangkan (Riduan, 2012:252):

$$
\mathrm{Y}=\mathrm{a}+\beta_{1} \mathrm{X}_{1}+\beta_{2} \mathrm{X}_{2}+\beta_{3} \mathrm{X}_{3}+\varepsilon
$$

Dimana :

$\mathrm{Y}=$ Pemahaman PSAK Konvergensi

$\mathrm{a}=$ Nilai Konstanta

$\mathrm{X}_{1} \quad=$ Minat Belajar

$\mathrm{X}_{2}=$ Ketersediaan Sarana Pendidikan

$\mathrm{X}_{3} \quad=$ Kompetensi Dosen

$\varepsilon=$ Error

$\beta_{1} \quad=$ Koefisien regresi variabel $\mathrm{X}_{1}$

$\beta_{2} \quad=$ Koefisien regresi variabel $\mathrm{X}_{2}$

$\beta_{3} \quad=$ Koefisien regresi variabel $\mathrm{X}_{3}$

\section{Koefisien Determinasi $\left(\mathbf{R}^{2}\right)$}

Koefisien Determinasi dilaksanakan agar dapat mengetahui persentase kontribusi variabel Minat Belajar, Ketersediaan Sarana Pendidikan, dan Kompetensi Dosen terhadap Pemahaman PSAK Konvergensi. Koefisien Determinasi meng ukur seberapa besar variabel independen mempengaruhi nilai variabel dependen secara keseluruhn. Dengan menggunakan rumus:

$$
K D=r^{2} \times 100 \%
$$


Uji Hipotesis

\section{Uji Simultan $(f$-test $)$}

Seluruh variabel dependen yang mempunyai pengaruh atau tidak terhadap variabel indenpenden bisa diketahui dengan Uji F. Priyatno (2013:48) Uji statistik F atau uji koefisien regresi secara serentak, yaitu uji yng dipergunakan agar mengetahui apakah terdapat pengaruh antara Minat Belajar, Ketersediaan Sarana Pendidikan, dan Kompetensi Dosen terhadap Pemahaman PSAK Konvergensi.

\section{Uji Parsial (t-test)}

Pengaruh variabel bebas secara individual terhadap variabel terikat dapat diketahui dengan melakukan uji t. Menurut Priyatno (2013:50) Uji t dimaksudkan untuk mengetahui pengaruh variabel independen terhadap variabel dependen secara individual atau secara parsial. Pengujian ini adalah signifikansi dan koefisiensi regresi. Pengambilan keputusan didapatkan brdasarkan perbandingan nilai $\mathrm{t}$ hitung masing-masing koefisien regresi dengan nilai t tabel sesuai dengan $\alpha=0,05$.

\section{HASIL DAN PEMBAHASAN}

\section{Deskripsi dan Karakteristik Responden}

Penelitian ini dilaksanakan pada mahasiswa S-1 program studi Akuntansi yang berstatus aktif di Kota Bogor dengan responden 235 mahasiswa. Pengumpulan data dilaksanakan dengan disebarkan kuesioner kepada mahasiswa. Peneliti menyebar 250 kuesioner untuk meminimalisir kuesioner yang cacat dan tidak kembali, maka disebar melebihi kebutuhan data penelitian sehingga kuesioner dapat terpenuhi dan digunakan sebagai data penelitian. Dari jumlah kuesioner yang disebar sebanyak 250, semua responden bersedia mengisi kuesioner dan dari jumlah itu terdapat kuesioner yang tidak terisi sempurna/rusak yaitu sebanyak 12 kuesioner. Selanjutnya setelah kuesioner yang sudah diterima diseleksi kembali untuk menghasilkan kuesioner yang dibutuhkan dalam penelitian. Karena penelitian ini hanya dibutuhkan responden sebanyak 235 mahasiswa, sehingga bisa diambil kesimpulan, bahwa kuesioer $100 \%$ terpenuhi dengan mengambil 235 kuesioner sebagai data penelitian dari 250 yang telah disebar dan mengabaikan kuesioner yang tidak terisi sempurna/rusak. Berikut ini yang menjadi sampel dalam penelitian disajikan dalam tebel 5 :
Tabel 5 : Rekapitulasi Karakteistik Responden

\begin{tabular}{cccc}
\hline No & $\begin{array}{c}\text { Kriteria } \\
\text { Responden }\end{array}$ & Karakteristik & $\begin{array}{c}\text { Jumlah/o } \\
\text { rang }\end{array}$ \\
\hline $\mathbf{1}$ & Jenis & Perempuan & 152 \\
& Kelamin & & $(65 \%)$ \\
$\mathbf{2}$ & Usia & $21-25 \mathrm{Th}$ & 200 \\
& & & $(85 \%)$ \\
$\mathbf{3}$ & Latar & IPS & $87(37 \%)$ \\
& Belakang & & \\
& Pendidikan & & \\
\hline
\end{tabular}

Sumber: Data diolah,2017

Berdasarkan tabel 5 menggambarkan bahwa karakteristik responden penelitian ini didominasi oleh perempuan yakni sebanyak 152 orang, dengan usia responden berkisar antara 2125 tahun yakni sebanyak 200 orang, dengan latar belakaang pendidikan yaitu berasal dari SMA (sekolah menengah atas) dengan jurusan IPS. Berdasarkan dengan karakteristik tersebut, mahasiswa S-1 akuntansi PT (Perguruan Tinggi) di Kota Bogor yang berstatus aktif berada pada usia yang produktif dan dilatarbelakang pendidikan berhubungan dengan jurusan yang dipilih pada saat SMA (sekolah menengah atas) dan dianggap telah memahami dalam melakukan penyusunan dan membaca laporan keuangan.

\section{Minat Belajar}

Rekapitulasi skor tanggapan mengenai minat belajar terdapat pada Tabel 6:

Tabel 6 Rekapitulasi Skor Tanggapan Variabel Minat Belajar

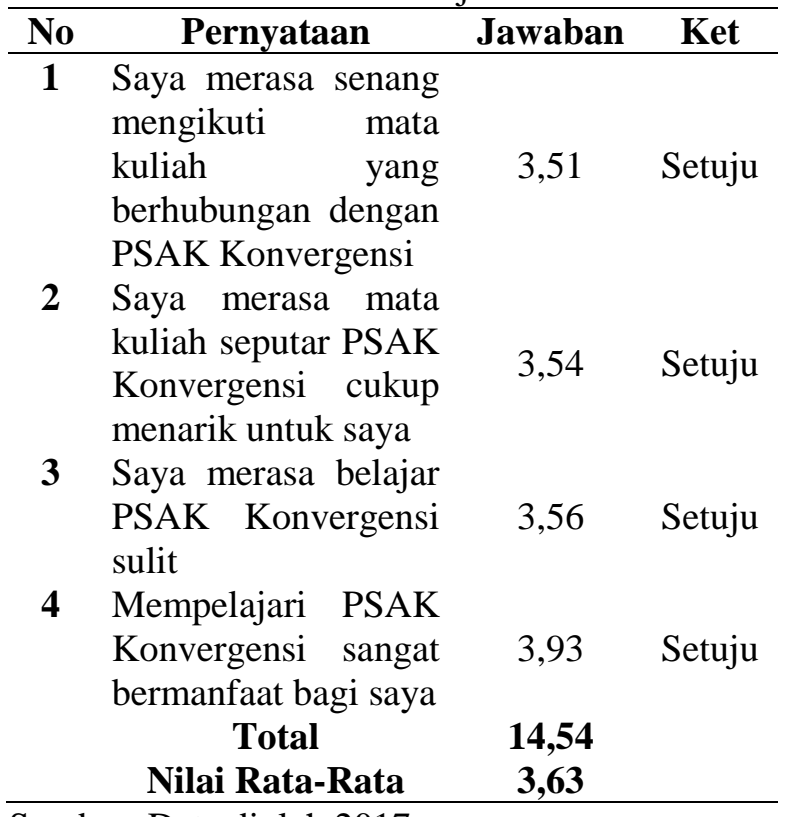

Sumber: Data diolah,2017

\section{Ketersediaan Sarana Pendidikan}

Rekapitulasi skor tanggapan ketersediaan sarana pendidikan terdapat pada Tabel 7 : 
Tabel 7 : Rekapitulasi Skor Tanggapan

Variabel Ketersediaan Sarana Pendidikan

\begin{tabular}{|c|c|c|c|}
\hline No & Pernyataan & Jawaban & Ket \\
\hline 1 & $\begin{array}{lr}\text { Gedung di } & \text { kampus } \\
\text { saya membuat saya } \\
\text { nyaman } \\
\text { belajar }\end{array}$ & 3,58 & Setuju \\
\hline 2 & $\begin{array}{lr}\text { Saya } & \text { selalu } \\
\text { mengikuti } & \text { mata } \\
\text { kuliah di ruang } \\
\text { kelas }\end{array}$ & 4,22 & $\begin{array}{l}\text { Sangat } \\
\text { Setuju }\end{array}$ \\
\hline 3 & $\begin{array}{lr}\text { Sarana } & \text { yang } \\
\text { disediakan } & \text { untuk } \\
\text { belajar } & \text { dikelas } \\
\text { sudah lengkap }\end{array}$ & 3,51 & Setuju \\
\hline 4 & $\begin{array}{l}\text { Fasilitas buku di } \\
\text { perpustakaan } \\
\text { kampus saya sudah } \\
\text { memadai }\end{array}$ & 3,09 & $\begin{array}{l}\text { Kurang } \\
\text { Setuju }\end{array}$ \\
\hline & $\begin{array}{c}\text { Total } \\
\text { Nilai Rata-Rata }\end{array}$ & $\begin{array}{l}14,4 \\
3,60\end{array}$ & Setuju \\
\hline
\end{tabular}

Sumber: Data diolah,2017

\section{Kompetensi Dosen}

Rekapitulasi skor tanggapan mengenai kompetensi dosen terdapat pada Tabel 8 :

Tabel 8 : Rekapitulasi Skor Tanggapan Variabel Kompetensi Dosen

\begin{tabular}{|c|c|c|c|}
\hline No & Pernyataan & Jawaban & Ket \\
\hline 1 & $\begin{array}{l}\text { Dosen selalu } \\
\text { memberikan silabus } \\
\text { yang berisi dengan } \\
\text { pembelajaran PSAK } \\
\text { Konvergensi }\end{array}$ & 3,54 & Setuju \\
\hline 2 & $\begin{array}{l}\text { Dosen berprilaku } \\
\text { mementingkan diri } \\
\text { sendiri }\end{array}$ & 3,56 & Setuju \\
\hline 3 & $\begin{array}{lr}\text { Dosen bersedia } \\
\text { mendengarkan kritik } \\
\text { dan } \\
\text { mahasiswa/i }\end{array}$ & 3,65 & Setuju \\
\hline 4 & $\begin{array}{l}\text { Dosen menguasasi } \\
\text { materi perkuliahan } \\
\text { secara luas termasuk } \\
\text { pemahaman PSAK } \\
\text { Konvergensi }\end{array}$ & 3,70 & Setuju \\
\hline & $\begin{array}{c}\text { Total } \\
\text { Nilai Rata-Rata }\end{array}$ & $\begin{array}{l}14,4 \\
3,61\end{array}$ & Setuju \\
\hline
\end{tabular}

Sumber: Data diolah,2017

\section{Pemahaman PSAK Konvergensi}

Rekapitulasi skor tanggapan mengenai pemahaman psak konvergensi terdapat pada Tabel 9:
Tabel 9 Rekapitulasi Skor Tanggapan Variabel Pemahaman PSAK Konvergensi

\begin{tabular}{|c|c|c|c|}
\hline No & Pernyataan & Jawaban & Ket \\
\hline 1 & $\begin{array}{l}\text { Metode direct dan } \\
\text { indirect digunakan } \\
\text { untuk menyajikan } \\
\text { arus kas dari } \\
\text { aktivitas operasi }\end{array}$ & 3,79 & Setuju \\
\hline 2 & $\begin{array}{l}\text { PSAK yang tidak } \\
\text { diatur dalam IFRS } \\
\text { dihapuskan }\end{array}$ & 3,48 & Setuju \\
\hline 3 & $\begin{array}{l}\text { Konsep principle } \\
\text { based accounting } \\
\text { menyebabkan } \\
\text { ketidakakuratan } \\
\text { informsi }\end{array}$ & 3,54 & Setuju \\
\hline 4 & $\begin{array}{l}\text { Terdapat perbedaan } \\
\text { arus kas antara } \\
\text { IFRS dan US } \\
\text { GAAP }\end{array}$ & 3,20 & $\begin{array}{c}\text { Kurang } \\
\text { Setuju }\end{array}$ \\
\hline 5 & $\begin{array}{l}\text { Fair value terjadi } \\
\text { jika ada transaksi } \\
\text { pertukaran aset }\end{array}$ & 3,67 & Setuju \\
\hline & $\begin{array}{c}\text { Total } \\
\text { Nilai Rata-rata }\end{array}$ & $\begin{array}{l}17,68 \\
3,53\end{array}$ & Setuju \\
\hline
\end{tabular}

Sumber: Data diolah,2017

\section{Koefisien Determinasi}

Koefisien determinasi dilakukan demi melihat besarnya kontribusi variabel minat belajar, ketersediaan sarana pendidikan, dan kompetensi dosen sama terhadap pemahaman PSAK Konvergensi. Koefisien determinasi didapat melalui cara mengkuadratkan koefisien korelasi yang telah ditemukan, dan selanjutnya dikalikan dengan $100 \%\left(\mathrm{r}^{2} \times 100 \%\right)$ atau bisa juga dengan langsung melihat nilai $\mathrm{R}$ Square $\left(\mathrm{R}^{2}\right)$. Hasil analisis diuraikan di tabel 10 :

Tabel 10: Koefisien Determinasi Model Summary ${ }^{\mathrm{b}}$

\begin{tabular}{|c|c|c|c|c|}
\hline \multicolumn{5}{|c|}{ Model Summary ${ }^{\mathrm{b}}$} \\
\hline Model & $\mathrm{R}$ & $\begin{array}{c}\mathrm{R} \\
\text { Square }\end{array}$ & $\begin{array}{l}\text { Adjusted } \\
\text { R Square }\end{array}$ & $\begin{array}{l}\text { Std. Error } \\
\text { of the } \\
\text { Estimate }\end{array}$ \\
\hline 1 & 714 & .510 & .503 & 1.676 \\
\hline
\end{tabular}

a. Predictors: (Constant), Kompetensi Dosen, Ketersediaan Sarana Pendidikan, Minat Belajar b. Dependent Variable: Pemahaman PSAK Konvergensi Sumber: Output pengolahan data dengan SPSS 22, 2017 
Berdasarkan tabel 10 diatas, diperoleh $\mathrm{R}^{2}$ ( $R$ Square) sebesar 0,510 atau (51\%). Hal ini menggambarkan bahwa kontribusi variabel variabel minat belajar, ketersediaan sarana pendidikan, dan kompetensi dosen terhadap pemahaman PSAK Konvergensi sebesar 51\%, sedangkan sisanya $49 \%$ dipengaruhi atau dijelaskan oleh variabel lain yang tidak dimasukan dalam model penelitian ini seperti status perguruan tinggi, kecerdasan emsional, kecerdasan intelektual, kesiapan belajar, dan perilaku belajar. Stndard Error of the Estimate adalah suatu ukuran yang banyak kesalahan model regresi dalam prediksikan nilai Y. dari hasil regresi didapat nilai 1.676 satuan, hal ini bermakna banyaknya kesalahan dalam prediksi pemamaham PSAK Konvergensi sebesar 1.676 satuan.

\section{Pengujian Instrumen Uji Validitas}

Uji validitas berguna untuk mengetahui sejauhmana ketepatan alat ukur statistic yang pakai untuk mengukr apa yang seharusnya diukur. Instrumen yang valid berarti alat pengukuran yang pakai untuk mendaapatkan data penelitian sudah tepat. Uji validitas menghitung korelasi antar masing-masing butir-butir pernyataan dengan skor total pada masing-masing variabel. Nilai tersebut kemudian dibandingkan dengan nilai $r_{\text {kritis. }}$ Hasil uji validitas variabel minat belajar $\left(\mathrm{X}_{1}\right)$, ketersediaan sarana pendidikan $\left(\mathrm{X}_{2}\right)$, kompetensi dosen $\left(\mathrm{X}_{3}\right)$, dan pemahaman PSAK Konvergensi (Y), diuraikan pada tabel 11:

Tabel 11 : Hasil Uji Validitas

\begin{tabular}{clccc}
\hline No & \multicolumn{1}{c}{ Variabel } & $\mathbf{r}_{\text {hitung }}$ & $\mathbf{r}_{\text {kritis }}$ & Ket \\
\hline $\mathbf{1}$ & Minat Belajar & 0,580 & 0,3 & Valid \\
$\mathbf{2}$ & Ketersediaan & 0,679 & 0,3 & Valid \\
& $\begin{array}{l}\text { Sarana Pendidikan } \\
\mathbf{3}\end{array}$ & & & \\
& Kompetensi & 0,667 & 0,3 & Valid \\
& $\begin{array}{l}\text { Dosen } \\
\mathbf{4}\end{array}$ & & & \\
& Pemahaman & 0,584 & 0,3 & Valid \\
& PSAK & & & \\
\hline
\end{tabular}

Sumber: Output pengolahan data dengan SPSS 22,2017

Berdasarkan nilai tersebut ditentukan nilai standar (r-kritis) adalah sebesar 0,3 hal tersebut senada dengan yang disampaikan oleh Sugiyono (2013:182) yang menjelaskan bahwa ketika nilai hitung besarnya $>$ atau $=0,3$ maka data tersebut valid. Semua pernyataan dari variabel independen (minat belajar, ketersediaan sarana pendidikan, dan kompetensi dosen) dan variabel dependen yaitu pemahaman PSAK Konvergensi dinyatakan layak (valid) karena $\mathrm{r}_{\text {hitung }}$ masing-masing pernyataan $>\mathrm{r}_{\text {kritis. }}$.

\section{Uji Reliabilitas}

Setelah dilakukan uji validitas, selanjutnya dilakukan uji reliabilitas. Uji reliabilitas dipakai agar mengetahui apakah kumpulan data yang dipakai mennjukan tingkat keteptan, keakuratan, kestabilan dan konsistensi alat tersebut, dan hasil pengukuran akan tetap konsisten apabila dilakukan pengukuran kembali. Hasil uji reliabilitas menunjukan seberapa jauh konsistensi keterpercayaan atas hasil jawaban responden terhadap instrumen/pernyataan yang diberikan. Untuk mengukur konsistensi interval penggunaan instrumen digunakan Cronbach Alpha, untuk mengetahui bahwa semua variabel dikatakan reliable, rata-rata nilai Cronbach Alpha harus $>$ atau $=0,6$. Hasil uji reliabilitas diuraikan pada tabel 12 :

Tabel 12 : Hasil Uji Reliabilitas

\begin{tabular}{|c|c|c|c|c|}
\hline $\begin{array}{l}\mathbf{N} \\
\mathbf{0}\end{array}$ & Variabel & $\begin{array}{c}\text { Cronbach' } \\
\text { s Alpha }\end{array}$ & $\begin{array}{r}\mathbf{r}_{\text {kriti }} \\
\mathrm{s}\end{array}$ & Ket \\
\hline 1 & $\begin{array}{l}\text { Minat } \\
\text { Belajar }\end{array}$ & 0,727 & 0,6 & $\begin{array}{c}\text { Reliabe } \\
1\end{array}$ \\
\hline 2 & $\begin{array}{l}\text { Ketersediaa } \\
\text { n Sarana } \\
\text { Pendidikan }\end{array}$ & 0,758 & 0,6 & $\begin{array}{c}\text { Reliabe } \\
1\end{array}$ \\
\hline 3 & $\begin{array}{l}\text { Kompetens } \\
\text { i Dosen }\end{array}$ & 0,724 & 0,6 & $\begin{array}{c}\text { Reliabe } \\
1\end{array}$ \\
\hline 4 & $\begin{array}{l}\text { Pemahama } \\
\text { n PSAK } \\
\text { Konvergen } \\
\text { si }\end{array}$ & 0,730 & 0,6 & $\begin{array}{c}\text { Reliabe } \\
1\end{array}$ \\
\hline
\end{tabular}

Sumber: Output pengolahan data dengan SPSS 22,2017

Berdasarkan nilai tersebut ditentukan nilai standar (r-kritis) adalah sebesar 0,6 hal tersebut senada dengan yang disampaikan oleh Sugiyono (2013:184) yang menjelaskan bahwa suatu instrumen dinyatakan reliabel bila koefisien > atau $=0,6$. Semua pernyataan dari variabel independen (minat belajar, ketersediaan sarana pendidikan, dan kompetensi dosen) dan variabel dependen yaitu pemahaman PSAK Konvergensi dinyatakan reliabel karena Cronbach's Alplha masing-masing pernyataan $>\mathrm{r}_{\text {kritis. }}$

\section{Hasil Analisa dan Pembahasan Analisa Regresi Berganda}

Analisis regresi linear bergnda dipakai untuk mengetahui hubungan fungsional dari beberapa variabl bebas secara bersama-sama terhadap variabel terikt, dan juga untuk 
mengetahui jika nilai variabel independen (Pemahaman PSAK Konvergensi) dinaikan atau diturunkan nilainya. Hasil regresi linear berganda disajikan pada tabel 13 :

Tabel 13 : Analisis Regresi Linier Berganda Coefficients $^{\text {a }}$

\begin{tabular}{|c|c|c|c|c|c|}
\hline \multirow[t]{2}{*}{ Model } & \multicolumn{2}{|c|}{$\begin{array}{c}\text { Unstandar } \\
\text { dized } \\
\text { Coefficient } \\
\text { s }\end{array}$} & $\begin{array}{c}\text { Stand } \\
\text { ardize } \\
\mathrm{d} \\
\text { Coeffi } \\
\text { cients }\end{array}$ & $\mathrm{T}$ & Sig \\
\hline & B & $\begin{array}{l}\text { Std. } \\
\text { Erro } \\
\mathrm{r}\end{array}$ & Beta & & \\
\hline $\begin{array}{l}1 \text { (Constant) } \\
1\end{array}$ & $\begin{array}{r}6.39 \\
8\end{array}$ & .813 & & 7.868 & $\begin{array}{r}.00 \\
0\end{array}$ \\
\hline Minat Belajar & .214 & .067 & .192 & 3.200 & $\begin{array}{r}.00 \\
2\end{array}$ \\
\hline $\begin{array}{l}\text { Ketersediaan } \\
\text { Sarana } \\
\text { Pendidikan }\end{array}$ & .266 & .075 & 291 & 3.548 & $\begin{array}{r}.00 \\
0\end{array}$ \\
\hline $\begin{array}{l}\text { Kompetensi } \\
\text { Dosen }\end{array}$ & .329 & .089 & .312 & 3.706 & $\begin{array}{r}.00 \\
0\end{array}$ \\
\hline
\end{tabular}

a. Dependent Variable: Pemahaman PSAK

Konvergensi

Sumber: Output pengolahan data dengan SPSS 22, 2017

Berdasarkan Tabel 11 diketahui bahwa nilai persamaan regresi adalah :

$$
\begin{gathered}
y=a+b_{1} x_{1}+b_{2} x_{2}+b_{3} x_{3}+\varepsilon \\
y=6.398+0,214 x_{1}+0,266 x_{2}+ \\
0,329 x_{3}+\varepsilon
\end{gathered}
$$

Interprestasi dari regresi tersebut adalah sebagai berikut :

1. Hasil prsamaan regresi tersebut diperoleh nilai konstanta sebesar 6.398, nilai tersebut memiliki makna bahwa jika seluruh variabel bebas yaitu minat belajar, ketersediaan sarana pendidikan, dan kompetensi dosen bernilai 0, maka pemahaman PSAK Konvergensi bernilai 6.389 atau nilai pemahaman PSAK Konvergensi tetap.

2. Hasil persamaan regresi untuk variabel minat belajar sebesar 0,214. Hal ini bahwa untuk setiap peningkatan penerapan minat belajar sebesar satu satuan, dengan asumsi variabel ketersediaan sarana pendidikan dan kompetensi dosen bernilai 0, maka menyebabkan meningkatnya pemahaman PSAK Konvergensi sebesar 0,214.

3. Hasil persamaan regresi untuk variabel ketersediaan sarana pendidikan sebesar 0,266. Hal ini bahwa untuk setiap peningkatan penerapan ketersediaan sarana pendidikan sebesar satu satuan, dengan asumsi variabel minat belajar dan kompetensi dosen bernilai 0 , maka menyebabkan meningkatnya pemahaman PSAK Konvergensi sebesar 0,266.

4. Hasil persamaan regresi untuk variabel kompetensi dosen sebesar 0,329. Hal ini bahwa untuk setiap peningkatan penerapan kompetensi dosen sebesar satu satuan, dengan asumsi variabel minat belajar dan ketersediaan sarana pendidikan bernilai 0 , maka menyebabkan meningkatnya pemahaman PSAK Konvergensi sebesar 0,329.

Berdasarkan hasil tersebut menggambarkan bahwa variabel kompetensi dosen $\left(X_{3}\right)$ merupakan variabel yang paling dominan dengan nilai 0,329 , artinya kompetensi dosen sangat mempengaruhi mahasiswa dalam pemahaman PSAK Konvergensi.

\section{Pengujian Hipotesis}

\section{Uji F-test}

Pengujian ini berguna untuk mengtahui pengaruh secara simultan minat belajar, ketersediaan sarana pendidikan, dan kompetensi dosen terhadap pemahaman PSAK Konvergensi. Maka hipotesisnya ialah :

$\mathrm{H}_{\mathrm{o}}: \beta_{1}, \beta_{2}, \beta_{3} \leq 0$; Minat Belajar, Ketersediaan Sarana Pendidikan, dan Kompetensi Dosen tidak berpengaruh secara simultan terhadap Pemahaman PSAK konvergensi.

$\mathrm{H}_{\mathrm{o}}: \beta_{1}, \beta_{2}, \beta_{3}>0$; Minat Belajar, Ketersediaan Sarana Pendidikan, dan Kompetensi Dosen berpengaruh secara simultan terhadap Pemahaman PSAK Konvergensi.

Hasil uji $\mathrm{F}$ dapat diperoleh melalui Tabel analisis varians (Anova) seperti yang terlihat pada Tabel 14:

\begin{tabular}{lccccc}
\multicolumn{6}{c}{ Tabel 14 : Uji F } \\
ANOVA \\
\hline $\begin{array}{l}\text { Mod } \\
\text { el }\end{array}$ & Sum of & Df & $\begin{array}{c}\text { Mean } \\
\text { Squares }\end{array}$ & F & Sig. \\
& \multicolumn{4}{c}{$\begin{array}{c}\text { Squar } \\
\text { e }\end{array}$} \\
\hline 1 & Regressi & 674.64 & 3 & 224.88 & 80.01 \\
& on & 8 & & 3 & 2 \\
& Residual & 649.25 & 231 & 2.811 & \\
& & 0 & & & \\
& Total & 1323.8 & 234 & & \\
& & 98 & & & \\
& &
\end{tabular}

a. Dependent Variable: Pemahaman PSAK Konvergensi

b. Predictors: (Constant) Ketersediaan Sarana Pendidikan, Minat Belajar Kompetensi Dosen, Sumber: Output pengolahan data dengan SPSS 22, 2017

Berdasarkan Tabel 14 dapat diketahui bahwa hasil pengujian menggunakan uji $F$, 


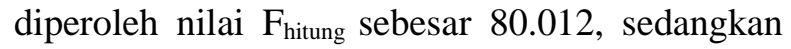
nilai $F_{\text {tabel }}$ sebesar 3,78. Apabila $F_{\text {hitung }}$ dibandingkan dengan $\mathrm{F}_{\text {tabel }}$, maka $\mathrm{F}_{\text {hitung }}>\mathrm{F}_{\text {tabel }}$ $(80.012>3,78)$ dengan nilai signifikasi $\mathrm{F}$ sebesar $0,00<0,05$. Hal ini berarti bahwa $\mathrm{H}_{\mathrm{o}}$ ditolak dan $\mathrm{H}_{\mathrm{a}}$ diterima. Kondisi ini bermakna bahwa minat belajar, ketersediaan sarana pendidikan, dan kompetensi dosen secara simultan berpngaruh positif terhadap pemahaman PSAK Konvergensi.

\section{Uji t-test}

Pengujian ini dilakukan untuk mengetahui pengaruh secarra parsiaal minat belajar, ketersediaan sarana pendidikan, dan kompetensi dosen terhadap pemahaman PSAK Konvergensi. Maka hipotesis yang digunakan adalah sebagai berikut:

$\mathrm{H}_{\mathrm{o}}: \beta_{1} \leq 0$;Minat belajar tidak berpengaruh terhadap pemahaman PSAK Konvergensi

$\mathrm{H}_{\mathrm{a}}: \beta_{1}>0$;Minat Belajar berpengaruh secara parsial terhadap pemahaman PSAK Konvergensi

$\mathrm{H}_{\mathrm{o}}: \beta_{2} \leq 0$;Ketersediaan sarana pendidikan tidak berpengaruh terhadap pemahaman PSAK Konvergensi

$\mathrm{H}_{\mathrm{a}}: \beta_{2}>0$; Ketersediaan sarana pendidikan berpengaruh terhadap pemahaman PSAK Konvergensi

$\mathrm{H}_{\mathrm{o}}: \beta_{3} \leq 0$;Kompetensi dosen tidak berpengaruh terhadap pemahaman PSAK Konvergensi

$\mathrm{H}_{\mathrm{a}}: \beta_{3}>0$;Kompetensi dosen berppengaruh terhadap pemahaman PSAK Konvergensi

Berdasarkan perhitungan diperoleh hasil berikut ini :

\begin{tabular}{|c|c|c|c|c|c|}
\hline & $\begin{array}{r}\mathrm{Tab} \\
\mathrm{C}\end{array}$ & $\begin{array}{l}115: \\
\text { efficie }\end{array}$ & & & \\
\hline Model & $\begin{array}{r}\text { Uns } \\
\text { di } \\
\text { Coet }\end{array}$ & $\begin{array}{l}\text { andar } \\
\text { ed } \\
\text { icien } \\
\text { s }\end{array}$ & $\begin{array}{l}\text { Standa } \\
\text { rdized } \\
\text { Coeffi } \\
\text { cients }\end{array}$ & $\mathrm{T}$ & Sig \\
\hline & B & $\begin{array}{l}\text { Std. } \\
\text { Erro } \\
\mathrm{r}\end{array}$ & Beta & & \\
\hline 1 (Constant) & $\begin{array}{r}6.39 \\
8\end{array}$ & .813 & & 7.868 & $\begin{array}{r}.00 \\
0\end{array}$ \\
\hline $\begin{array}{l}\text { Minat } \\
\text { Belajar }\end{array}$ & .214 & .067 & .192 & 3.200 & $\begin{array}{r}.00 \\
2\end{array}$ \\
\hline $\begin{array}{l}\text { Ketersediaa } \\
\text { n Sarana } \\
\text { Pendidikan }\end{array}$ & .266 & .075 & .291 & 3.548 & $\begin{array}{r}.00 \\
0\end{array}$ \\
\hline $\begin{array}{l}\text { Kompetensi } \\
\text { Dosen }\end{array}$ & .329 & .089 & .312 & 3.706 & $\begin{array}{r}.00 \\
0\end{array}$ \\
\hline
\end{tabular}

a. Dependent Variable: Pemahaman PSAK

Konvergensi

Sumber: Output pengolahan data dengan SPSS

22, 2017

\section{Uji t Variabel Minat Belajar}

Uji $\mathrm{t}$ diperoleh nilai thitung untuk minat belajar sebesar 3.200, sedangkan nilai tabel sebesar 1.970. Apabila $t_{\text {hitung dibandingkan dengan } t_{\text {tabel }}}$ maka $t_{\text {hitung }}>t_{\text {tabel }}(3.200>1.970)$ dengan tingkat signifikan $0.002<0.005$. Hal ini berarti bahwa $\mathrm{H}_{\mathrm{o}}$ ditolak dan $\mathrm{H}_{\mathrm{a}}$ diterima. Kondisi ini bermakna bahwa minat belajar secara parsial berpengarh positif terhadap pemahaman PSAK Konvergensi.

\section{Uji $t$ Variabel Ketersediaan Sarana Pendidikan}

Hasil pengujian uji $t$ diperoleh nilai $t_{\text {hitung }}$ untuk ketersediaan sarana pendidikan sebesar 3.548, sedangkan nilai $t_{\text {tabel }}$ sebesar 1.970. Apabila $t_{\text {hitung }}$ dibandingkan dengan $t_{\text {tabel }}$ maka $t_{\text {hitung }}>t_{\text {tabel }}$ $(3.548>1.970)$ dengan tingkat signifikan $0.000<$ 0.005 . Hal ini berarti bahwa $\mathrm{H}_{\mathrm{o}}$ ditolak dan $\mathrm{H}_{\mathrm{a}}$ diterima. Kondisi ini bermakna bahwa ketersediaan sarana pendidikan secara parsial berpengaruh positif terhadap pemahaman PSAK Konvergensi.

\section{Uji t Variabel Kompetensi Dosen}

Hasil pengujian dengan menggunakan uji $\mathrm{t}$ diperoleh nilai $\mathrm{t}_{\text {hitung }}$ untuk kompetensi dosen sebesar 3.706, sedangkan nilai $t_{\text {tabel }}$ sebesar 1.970. Apabila $t_{\text {hitung }}$ dibandingkan dengan $t_{\text {tabel }}$ maka $t_{\text {hitung }}$ $>\mathrm{t}_{\text {tabel }}(3.706>1.970)$ dengan tingkat signifikan $0.000<0.005$. Hal ini berarti bahwa $\mathrm{H}_{\mathrm{o}}$ ditolak dan $\mathrm{H}_{\mathrm{a}}$ diterima. Kondisi ini bermakna bahwa kompetensi dosen secara parsial berpengaruh positif terhadap pemahaman PSAK Konvergensi.

\section{Pembahasan \\ Uji F}

Berdasarkan hasil uji simultan, menunjukan bahwa minat belajar, ketersediaan sarana pendidikan, dan kompetensi dosen berpengaruh positif terhadap pemahaman PSAK Konvergensi, artinya jika mahasiswa memiliki minat belajar yang tinggi, karena sadar akan pentingnya pemahaman PSAK Konvergensi. Pentingnya minat belajar seseorang dapat diketahui serta dijelaskan bawha mahasiswa memiliki ketertarikan dalam belajar yang timbul dan tidak ada pemaksaan serta akan mendorong untuk belajar dan selalu berusaha menghasilkan pemahamn yang bagus dalam mempelajari PSAK Konvergensi. Pentingnya Ketersediaan sarana pendidikan dalam memahami PSAK Konvergensi dapat dijelaskan bahwa semakin lengkap ketersediaan sarana pendidikan yang disediakan oleh pihak PT (Perguruan Tinggi) maka semakin baik pemahaman PSAK Konvergensi yang dimiliki mahasiswa yang dapat dipergunakan 
mahasiswa secara langsung seperti tersedianya buku mengenai PSAK Konvergensi, serta tersedianya internet di dalam kampus untuk mencari informasi mengenai PSAK Konvergensi. Pentingnya kompetensi dosen dalam pemahaman PSAK Konvergensi dapat diketahui dosen memiliki kompeten ialah faktor yang bisa memberikan contoh baik bagi mahasiswa untuk belajar, dan dosen memiliki kompeten dinilai dari seberapa banyak dosen memahami dan menguasai materi PSAK Konvergensi dan cara penyampaian dosen terhadap mahasiswanya. Hal ini sejlan dengan teori Sulastri dalam Christiani (2015:10), mengemukakan bahwa pemahaman merupakan kemahiran suatu orang untuk mengerti dan memahami sesuatu setelah sesuatu tersebut diketahui dan diingatkan.

\section{Uji t}

\section{Pengaruh Minat Belajar}

Berdasarkan hasil pengujian secara parsial variabel minat belajar berpengaruh positif terhadap pemahaman PSAK Konvergensi. Hasil penelitian tersebut membuktikan bahwa adanya pengaruh minat belajar terhadap pemahaman PSAK Konvergensi pada mahasiswa S-1 akuntansi perguruan tinggi yang berstatus aktif di Kota Bogor. Minat belajar menjadi pertimbangan dalam pemahaman PSAK Konvergensi, karena minat belajar seseorang dapat muncul ketika seseorang tersebut memperhatikan suatu kegiatan dengan sebuah cara usaha yang dilaksanakan orang agar mendapatkan perubahan dengan menimbulkan perasaan senang dengan mata kuliah berkaitan dengan PSAK Konvergensi berkarena merasa sangat bermanfaat untuk dirinya sendiri dan cenderung akan mudah memahami pelajaran yang disukai tersebut. Adanya pengaruh minat belajar terhadap pemahaman PSAK Konvergensi pada mahasiswa S-1 Akuntansi perguruan tinggi yang berstatus aktif di Kota Bogor menjadi hal yang perlu diperhatikan terutama pada pihak perguruan tinggi yang sebaiknya lebih dapat memotivasi mahasiswa untuk dapat mengembangkan minat dalam belajar sehingga mahasiswa akan belajar bersungguh-sungguh dalam mempelajari dan memahami PSAK Konvergensi.

Hasil penelitian ini mendukung penelitian yang dilakukan oleh Nugraheni (2012:26), yang menunjukan bahwa semakin tinggi minat seseorang maka semakin meningkatkan pemahaman IFRS mahasiswa.

\section{Pengaruh Ketersediaan Sarana Pendidikan}

Berdasarkan Pengujan parsial variabel minat belajar berpengaruh positif terhadap pemahaman PSAK Konvergensi. Hasil penelitian tersebut membuktikan bahwa adanya pengaruh minat belajar terhadap pemahaman PSAK Konvergensi pada mahasiswa S-1 akuntansi perguruan tinggi yang berstatus aktif di Kota Bogor. Minat belajar menjadi pertimbangan dalam pemahaman PSAK Konvergensi, karena minat belajar seseorang dapat muncul ketika seseorang tersebut memperhatikan suatu kegiatan dengan sebuah cara usaha yng bisa dilaksanakan suatu orang untuk mendapatkan perubahan dengan menimbulkan perasaan senang dengan mata kuliah yang memiliki kaitan dengan PSAK Konvergensi berkarena merasa sangat memberikan manfaat untuk individu sendiri serta cenderung akan mudah memahami pelajaran yang disukai tersebut. Adanya pengaruh minat belajar terhadap pemahaman PSAK Konvergensi pada mahasiswa S-1 Akuntansi perguruan tinggi yang berstatus aktif di Kota Bogor menjadi hal yang perlu diperhatikan terutama pada pihak perguruan tinggi yang sebaiknya lebih dapat memotivasi mahasiswa untuk dapat mengembangkan minat dalam belajar sehingga mahasiswa akan belajar bersungguhsungguh dalam mempelajari dan memahami PSAK Konvergensi.

Hasil penelitian ini sejalan dengan teori minat belajar menurut Slameto (2010:57), menyebutkan bahwa minat yaitu kecnderungan yang teetap dalam memperhatikan dan mengingat suatu kejadian dan kegiatan. Kegiatan itu diminati, diikuti secara berulng kali serta diikuti perasaan bahagia sehingga diperoleh kepuasan. Artinya dengan memiliki minat belajar yang baik pada matakuliah yang berkaitan dengn PSAK Konvergensi dengan didampingi perasaan bahagia dan diikuti berulang kali, sehingga dapat berpengaruh terhadap pemahaman PSAK Konvergensi.

Hasil penelitian ini mendukung penelitian yang dilakukan oleh Nugraheni (2012:26), yang menunjukan bahwa semakin tinggi minat seseorang maka semakin meningkatkan pemahaman IFRS mahasiswa.

\section{Pengaruh Kompetensi Dosen}

Berdasarkan hasil pengujian secara parsial variabel kompetensi dosen berpengaruh positif terhadap pemahaman PSAK Konvergensi. Hasil penelitian tersebut membuktikan bahwa adanya pengaruh kompetensi dosen terhadap pemahaman PSAK Konvergensi pada mahasiswa S-1 akuntansi perguruan tinggi yang berstatus aktif di Kota Bogor, karena dosen yang memiliki kompeten 
ialah faktor yang dapat memberikan contoh yang baik dan memberikan semangat tinggi mahasiswa untuk belajar. Dosen yang memiliki kompeten dapat diliht dari seberapa tinggi dan seberapa menguasai bahan ajar dan bisa menerapkan model belajar yang begitu tepat. Sehingga dengan dosen yang berkompeten dapat memudahkan dan memotivasi mahasiswa dalam memahami PSAK Konvergensi dengan memberikan pembekalan ilmu yang sangat bermanfaat bagi mahasiswa. Adanya pengaruh kompetensi dosen terhadap pemahaman PSAK Konvergensi pada mahasiswa S-1 Akuntansi perguruan tinggi yang berstatus aktif di Kota Bogor merupakan hal yang menjadi pertimbangan dalam pemahaman PSAK Konvergensi dan perlu diperhatikan oleh lembaga pendidikan, pemerintah, serta PT (Perguruaan Tinggi) dengan meningkatkan kualitas dosen, karena dosen dalam hal ini berperan sebagai sumber pengetahuan utama dan pertama bagi mahasiswa di perguruan tinggi.

Hasil penelitian ini sejalan dengan teori Wibowo (2007:86), kompetensi dinilai seperti keahlian untuk melaksanakan pekerjaan maupun kewajiban yang didampingi dengan keahlian (keterampilan) dan imlu pengetahun kerja yang diharuskan oleh pekerjaan. Artinya dosen yang berkompeten memiliki peranan penting dalam belajar membimbing dan sebagai sumber ilmu pengetahuan serta mengarahkan mahasiswa ke lingkungan yang baik, memotivasi mahasiswa supaya bertambah giat dan semangat belajar dengan keterrampilan dan ilmu pengetahuan yang dimilikinya. Hasil penelitian ini mendukung penelitian yang dilakukan oleh Utami (2012:29), hasil menunjukan bahwa apabila mahasiswa mempunyai persepsi bahwa dosen akan memotivasi mahasiswa untuk menyukai bahan ajar yang diberikan oleh dosen kemudian mahasiwa akan mempelajarinya, apabila dosen pengampu mereka berkompeten dan mahasisswa bisa mempunyai motivasi belajar tinggi karena mahasiswa merasa nyaman dan beranggapan dosen dapat dijadikan tempat mendalami ilmu ketika mereka belum paham terhadap suatu materi.

\section{SIMPULAN}

1. Karakteristik responden dalam penelitian ini yaitu mahasiswa yang didominasi oleh perempuan sebanyak 152 orang, dengan usia responden berkisar antara 21-25 tahun sebanyak 200 orang dengan latar belakang pendidikan berasal dari jurusan IPS sebanyak 87 orang. Berdasarkan tanggapan responden mengenai penelitian ini, pada masing-masing variabel secara umum adalah setuju.
2. Minat Belajar, Ketersediaan Sarana Pendidikan, dan Kompetensi Dosen secara simultan berpengaruh positif terhadap pemahaman PSAK Konvergensi.

3. Minat Belajar, Ketersediaan Sarana Pendidikan, dan Kompetensi Dosen secara parsial berpengaruh positif terhadap pemahaman PSAK Konvergensi.

4. Berdasarkan hasil pengujian analisis regresi linear berganda dapat diketahui bahwa faktor yang paling dominnan dalam pemahaman PSAK Konvergensi pada mahasiswa S-1 akuntansi PT (Perguruan Tinggi) yang berstatus aktif di Kota Bogor adalah Kompetensi Dosen.

\section{DAFTAR PUSTAKA}

Badan Pusat Statistik Provinsi Jawa Barat, 2015, Provinsi Jawa Barat Dalam Angka. http//jabar.bps.go.id Diakses pada 26 Februari 2017 pukul 14.09

Christiani,Yuningsih Nita, 2015, Pemahaman

Mahasiswa Akuntansi Terhadap

International Financial Reporting

Standar (IFRS), Tesis. Universitas

Kristen Satya Wacana. Salatiga

Edukasi Kompas, 2016, Lulusan Perguruan

Tinggi Semakin Sulit,

http://edukasi.kompas.com. Diakses pada

04 Februari 2017 pukul 15.40

E.Mulyasa, 2004, Manajemen Berbasis

Sekolah, PT Remaja Rosdakarya.

Bandung

Ghozali, Imam, 2011, Aplikasi Analisis Multivariate dengan Program SPSS, Badan Penerbit Universitas Diponogoro, Semarang.

Herbert, Wilson, Loraver Tsebga, Adaeze, Ohanele, Iheanyi, Anyahara, 2013, Adoption of International Financial Reporting Standars (IFRS) Insights from Nigerian Academics and Prancitioners, Journal of Finance and Accounting, Vol 4, No 6.

Mahendra, Reza, 2013, Dampak Konvergensi

PSAK ke IFRS Terhadap Arus Kas

Pada PT Rimo Catur Lestari Tbk

Periode 2010-2011 Dalam Pengambilan

Keputusan Investasi, Penulisan Ilmiah,

Program Studi Stara Satu Manajemen

Program Pasca Setara Sarjana Muda,

Unversitas Gunadarma, Depok.

Mukmin, M. N., \& Wulansari, H. (2017). AKUNTABILITAS KINERJA AKUNTAN 
PENDIDIK BERDASARKAN KOMPETENSI AKUNTAN DAN ETIKA PROFESIONAL (Studi Empiris Pada Perguruan Tinggi Swasta di Bogor). JURNAL AKUNIDA, 3(2), 56-65.

Mukmin, M. N., \& Gusprasetyo, G. (2017). PENGARUH INVESTASI ASET TETAP DAN BIAYA OPERASIONAL TERHADAP PENDAPATAN OPERASIONAL PADA PT. SANSHIRO HARAPAN MAKMUR. JURNAL AKUNIDA, 3(1), 20-28.

Nugraheni, Diana dan Ardiani Ika Sulistyawati, 2012, Faktor-Faktor Yang Mempengaruhi Tingkat Pemahaman IFRS Pada Mahasiswa Program Studi S-1 Akuntansi Perguruan Tinggi di Kota Semarang, Fakultas Ekonomi Universitas Semarang, Jurnal Akuntansi Vol 1, No.1, Januari, halaman 13-16.

Priyatno, Duwi, 2013, Analisis Korelasi Regresi dan Multivariate dengan SPSS, Gava Media. Yogyakarta

Riduan, 2012, Metode dan Teknik Menyusun Proposal Penelitian, Alfabeta. Bandung

Slameto, 2010, Belajar dan Faktor-faktor Yang Mempengaruhinya, Rineka Cipta. Jakarta

Sugiyono,2011, Metode Penelitian Bisnis (Pendekatan Kuantitatif Kualitatif, dan R\&D), Alfabeta. Bandung

,2013, Metode Penelitian Bisnis (Pendekatan Kuantitatif Kualitatif, dan R\&D), Alfabeta. Bandung

Tu'u, Tulus, 2004, Peran Disiplin Pada

Perilaku dan Prestasi Siswa, Grasindo.

Jakarta.

Undang-Undang Republik Indonesia, 2005,

Tentang Guru dan Dosen.

http://sindikker.dikti.go.id. Diakses pada 03 Maret 2017 pukul 20.24

Utami,Nadhia Riesthi Putri,2012, Pengaruh Status Perguruan Tinggi, Status Mahasiswa, Kecerdasan Emosional, dan Persepsi Mahasiswa Mengenai Kompetensi Dosen Terhadap Pemahaman IFRS Pada Mahasiswa Akuntansi Kota Semarang, Skripsi, Universitas Diponogoro, Semarang.

Wibowo, 2007, Manajemen Kinerja, PT. Raja Grafindo Persada. Jakarta. 